\title{
The Innovation of Online-Based Social Studies Lesson Plan Models to Face the Industrial Revolution 4.0
}

\author{
$1^{\text {st }}$ Erlina Wiyanarti* \\ Department of Social Studies Education \\ Faculty of Social Science Education, \\ Universitas Pendidikan Indonesia, Bandung, \\ Indonesia \\ erlinaw@upi.edu
}

\author{
$2^{\text {nd }}$ Mina Holilah \\ Department of Social Studies Education \\ Faculty of Social Science Education, \\ Universitas Pendidikan Indonesia, Bandung, \\ Indonesia \\ minaholilah@upi.edu
}

\begin{abstract}
The 4.0 industrial revolution brought significant changes to the practical and efficient modern human life through the acceleration of online-based digital technology. This condition must be responded quickly by the education system as one of the critical elements in society. This study aims to suggest the development of online-based social studies lesson plan models as learning innovations in the era of the industrial revolution 4.0. The research method used comparative descriptive with observation, interviews, and literature study of data collection techniques. The results showed that the development of online lesson plan models for social studies learning tools was carried out by teachers to answer the needs of an efficient future learning system. The
\end{abstract}

\section{INTRODUCTION}

Based on the survey results of the Center for Information and Communication Technology Education and Culture in 2018, revealed that only $40 \%$ of teachers in Indonesia are literate in Information and Communication Technology (ICT). The rest are still stuttering with advancements in the digital era [1]. These conditions are issues that must be dealt with quickly so that education in Indonesia can adjust to the demands of the times in the current industrial revolution 4.0 era. The Industrial Revolution 4.0 was born as a digital era, marked by the acceleration of distributed technology information faster and faster throughout the model must pay attention to the availability of technology, infrastructure, and qualified human resources. Developing achievement indicators, materials, models, methods, media, and learning evaluations that contain aspects of knowledge, attitudes, skills in utilizing digital devices to support the online lesson plan progress. Constraints faced are a lack of human resources' ability to operate online devices, limited infrastructure, and difficulties in adjusting learning devices that accommodate current curriculum goals. It concluded that online-based learning planning models implemented with the support of government, schools, and teacher's abilities.

Keywords-Social Studies, Online BasedLesson Plan, Industrial Revolution 4.0

world and led to an increase in the knowledge of internet users. Thus the education system must be able to adapt to the needs of this digital era, one of which is by developing online-based study plan innovations.

An online-based social studies lesson plan is a learning innovation that carried out while still referring to the Minister of Education and Culture Regulation No. 22 of 2016 concerning the standards of the primary and secondary education process. The principle of the social studies lesson plan in schools held interactively, inspirational, fun, challenging, motivating students to actively participate, responsive to technological developments, as well as providing 
ample space for the development of creativity and independence of students. For this reason, social studies lesson is designed to improve the efficiency and effectiveness of the achievement of graduate competencies by paying attention to the development of digital technology and the demands of the needs of society in the current global era.

The 2013 curriculum (K.13) applied in the Indonesian education system has qualification criteria for graduate competencies, which include aspects of knowledge, attitudes, and skills. Every student must be able to develop these abilities, as well as in developing their abilities in the digital age of this modern life. Thus, as a positive response to these conditions, the author researched the online-based social studies lesson plan in the 2013 Curriculum at Middle School as one of the learning innovation references in the face of the industrial revolution 4.0. Specifically, in this study lesson plan is not designed full online; there is a division of time proportions between face to face and online.

In a simple paradigm, the development of online-based lesson plan as developed by researchers (2019), illustrated in the flowchart as follows:

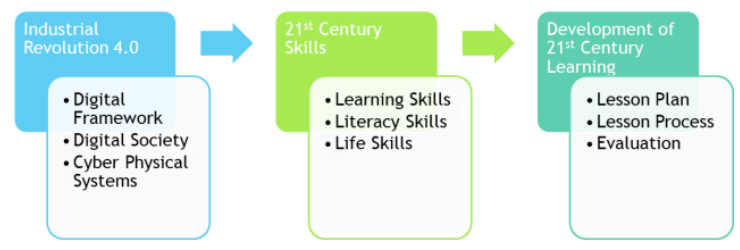

Figure 1 Framework for Developing an OnlineBased Lesson Plan

The design in chart 1 illustrates that the existence of digital work patterns, digital citizens, digital-physical systems, which then formed a digital society, is marking the industrial revolution era 4.0. This condition has implications for the importance of developing 21st century skills which include: (1) learning skills, (2) literacy skills from technology-media information, and (3) life skills or more broadly stated by [14] as ways of thinking, ways of working, tools for working, and living in the world. The lesson is expected to develop 21stcentury skills by stimulating students to be able to learn, innovate, use technology and information media, and have life and career skills to be able to survive, compete, and successfully live their lives. Then an alternative solution is to develop social studies lessons through innovative lesson plan design tools, lesson process collaboration, and evaluation sets that are carried out online to support efforts to achieve 21stcentury skills.

The lesson plan is an essential part of teaching, which consists of several aspects, which include goals, objectives, activities, media, and assessment. The document contains the design of what, when, where, and by which method participants must learn and how they should be assessed [3]. Teachers can use lesson plans to interpret it as a guide about what students need to learn and how it will be done effectively during class learning [4]. Before the lesson plan, teachers must identify the lesson objectives to be achieved, then design appropriate lesson activities to get feedback from students. The success of the lesson plan shown if he can discuss and integrate the three main components, which include the lesson objectives, lesson steps, and achievement of the lesson objectives themselves that identified through the evaluation tools used and teacher observations during the lesson process.

Based on the previous study on the development of lesson plans, the results of [5] study show that unplanned lesson and not adapted to the diversity of students' abilities will impact on the limitations of achieving cognitive activation of students. Therefore the teacher must design a lesson plan by paying attention to students 'thinking skills, studying students' opinions so that lesson objectives can be achieved. The teacher must be able to answer the question of what a lesson plan is? Do she/he have to prepare a lesson plan? How can she/he prepare a lesson plan? Moreover, what are the essential elements of the lesson plan? [7]. Lesson plans must design in detail based on the needs of each education/school unit, including the hours 
available for the subject, the specificity of the school, as well as the teaching methods and technology that will be used[8].

The importance of developing online-based lesson plans is based on a desire to improve the digital literacy skills of social studies teachers in Indonesia. Based on [9], he suggested that the internet is a valuable source of information as a valuable additional lesson tool. The internet can motivate students, make teaching more enjoyable, and allow variations in the vital lesson. However, the internet has significant weaknesses, namely student cheating, unreliable reference information, and technical problems using the internet both by students and teachers. It is essential to hold a special workshop to train teachers to design online-based lessons by utilizing existing internet facilities, of course, by paying attention to these weaknesses [10].

Online-based lesson has implications for teacher must be able to decide on the appropriate application or web in the preparation of the lesson by adjusting the lesson plans prepared. This implementation can be done by creating new online-based lesson plans or modifying lesson plans that have prepared in a conventional lesson with an online lesson. Besides, it must observe cases and needs that are typical in the class [11].

In online social studies lesson plans, teachers must also pay attention to elements of the description of lesson activities that include internet technology usage, the time period needed, a description of the lesson plan that has been set according to the template, and the possibility of using flexible information [12]. The online lesson plan aims to integrate rich learning content into a digital-based framework. It is a planning model to help teachers develop learning through a simple web that allows them to search, select, order, and quickly collect learning content that is relevant to the topics they want to teach [13].

\section{METHOD}

The research method used comparative descriptive with observations, interviews, literature study of data collection techniques. This study conducted on students' class of 2016 who contracted the Curriculum Study and Study Plan courses in the even semester of the 2018/2019 school year at the Social Sciences Study Program, Social Science Education Faculty of Universitas Pendidikan Indonesia. The author used a comparative descriptive method to get a picture of the differences in lesson plans made by students as prospective social studies teachers with two approaches, namely conventional lesson approaches, and online-based lesson approaches. The intended online is not fully online, but there is an equal division between face-to-face and online meetings. Data collection techniques through observation, interviews, and literature study to obtain a complete picture of how students develop online-based lesson plans based on needs analysis in schools and current technological developments. Of course, by using 2013 curriculum documents and remain guided by the Ministry of Education and Culture regulations No. 22 of 2016 concerning the status of secondary and a lesson plan is education processes.

\section{RESULTS AND DISCUSSION}

The results showed that the development of online-based lesson plans in social studies lessons became one of the alternative innovations of effective lesson systems in the future. Implementing a fully online or half-online system with the division of face-to-face proportions in class. As for what primary in this research is the lesson plan for the benefit of half-online with the consideration that the lesson process still requires a face-to-face process in class. The lesson plan refers to Curriculum 2013, designed for one or more meetings in the form of development of the syllabus to achieve Basic Competence (BC). The framework for the preparation of online-based lesson plans illustrated in Figure 2 below. 


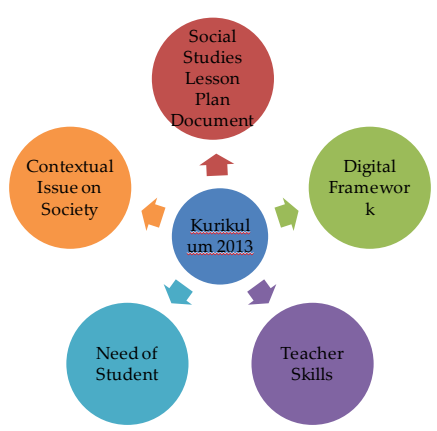

Figure 2 Framework for Developing an Online-Based Lesson Plan

Based on fig. 2, the 2013 curriculum is the leading spirit in the development of the Social Studies Study Plan. The study plan document is structured based on the mapping of achievement of Core Competencies and Basic Competencies. A unique characteristic of an online-based study plan is that they use a digital framework both for tracking lesson plan resources, using digital technology as a medium, working on onlinebased tasks, and other aspects. Of course, this is inseparable from the teacher's competence in using digital technology and paying attention to students' needs for what developed in an online lesson. Next, the typical development of social studies lessons emphasizes contextual issues in society, especially digital society, along with the accompanying issues.

The lesson plan components are designed to refer to the lesson plan guidelines set by the Ministry of Education and Culture. The components include (1) school identity, (2) identity of the subject or theme/sub-theme, (3) class/semester, (4) subject matter, (5) time allocation, (6) lesson objectives, (7) basic competency and indicators, (8) lesson materials, (9) lesson methods, (10) lesson media, (11) lesson resources, (12) lesson steps, and (12) assessment. A distinctive feature of the online-based lesson plan is to insert aspects of skills using technology both as lesson objectives and the use of several digital applications in lesson resources, media, and evaluation tools. It also designed a learning process with a teleconference system through the use of SPADA, Webinars, internal school websites, or other websites that support.

The study plan model must pay attention to the availability of technology, infrastructure, and teacher competencies in using digital technology. Developing online-based lesson now is no longer impossible; almost everyone has come into contact with digital technology. The issue of limited technology and infrastructure dealt with by utilizing smartphones because, in the modern era, almost everyone has a smartphone. Teachers and students can use computer or laptop devices that connected to the internet network, and even they can use tablets and smartphones that operated anywhere and anytime. The main problem is in the teacher's competence in operating the device. An online-based lesson is still a new thing in Indonesia, and therefore, there is a need for ongoing training to popularize online system with teachers. Technically, the flow of the preparation of online-based social studies lesson plans illustrated in the following figure 3 below.

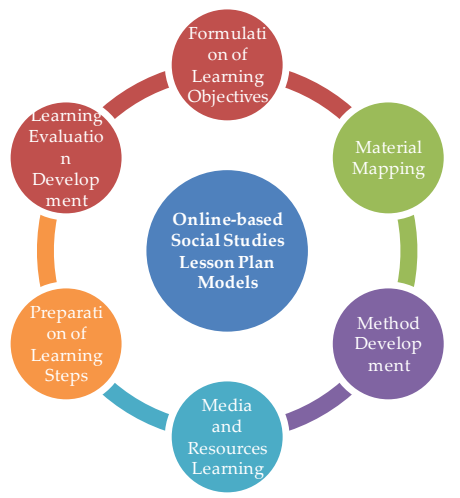

Figure 3 Online-Based Social Studies Lesson Plan Compilation, Research data source (2019) [1].

The first aspect that is done when creating an online-based social studies lesson plan is formulating lesson objectives. Lesson objectives are formulated based on $\mathrm{BC}$, using operational verbs that can be observed and measured, which include attitudes, knowledge, and skills. Teachers can use operational words that stimulate students to think, create, and act wisely in combining mastery of social studies material with digital technology along with the contextual issues that 
accompany it. The lesson objectives accommodate not only the mastery of social studies material but also the students' skills in operating an online website. Besides, aspects of attitude must also be considered, including discipline, honesty in doing work, intellectuals as scientists in using reliable internet reference sources, anti-plagiarism, and others. The operational words that can be developed by the teacher can be seen in Table 1 below:

Table. 1 Operational Words Formulation of Lesson Objectives

\begin{tabular}{llr}
\hline $\begin{array}{c}\text { Attitudes } \\
\text { Aspects }\end{array}$ & $\begin{array}{l}\text { Knowledge } \\
\text { Aspects }\end{array}$ & $\begin{array}{l}\text { Skills } \\
\text { Aspects }\end{array}$ \\
\hline Received & Understand & \multicolumn{1}{c}{ Try } \\
\hline Appreciate & Apply & Practice \\
\hline Running & Analyze & Operate \\
\hline Practice & Elaborate & Create \\
\hline $\begin{array}{l}\text { Appreciate, } \\
\text { etc. }\end{array}$ & $\begin{array}{l}\text { Evaluate, } \\
\text { etc. }\end{array}$ & $\begin{array}{l}\text { Modify, } \\
\text { etc. }\end{array}$ \\
\hline \multicolumn{3}{c}{ Research Data Sources (2019) } \\
\end{tabular}

Mapping of learning material is carried out by containing facts, concepts, principles, and relevant procedures following the formulation of lesson indicators. Contextual material also needs to be related to issues that occur in the social environment in the digital age. Examples include the use of social media, cyberbullying, cybercrime, mental disorders due to online games, and others. Mapping the material needs to insert aspects of the discussion that encourage students to search independently from the internet. In mapping the material, the teacher must be able to package the description/independently interesting description not only in the form of hard files, but also in the form of soft files that can be loaded and accessed on the online web in the form of PPT material, PDF files, and educational videos.

The formulation of approaches, models, methods, and lesson techniques are used by educators to create a learning atmosphere and lesson process so that students reach basic competence that tailored to the characteristics of students. The choice of lesson approach has a unique character in online-based lesson plans. In addition to using scientific approaches and other lesson models suggested by the government in current lesson plans, teachers can develop their creative approaches, models, methods, and learning techniques. One example that developed is the approach of Science, Technology, and Society (STS), web-based lesson models, projectbased lesson, problem-based learning, and others.

The next component is the media and lesson resources, both of which become the primary key in the development of online-based lesson plans. Learning media is a tool for the lesson process to deliver subject matter. The source of the lesson is everything that contains information that supports the understanding of students in the lesson, can be in the form of books, the internet, print media, electronics, the environment, or other relevant lesson resources. In online-based lesson plans, teachers must, of course, use a unique website designed in full for lesson activities. Besides, teachers can also take advantage of specific sites in general, including Google Classroom, SPADA, and others. The following is an example of a web page used explicitly for online learning at Universitas Pendidikan Indonesia.

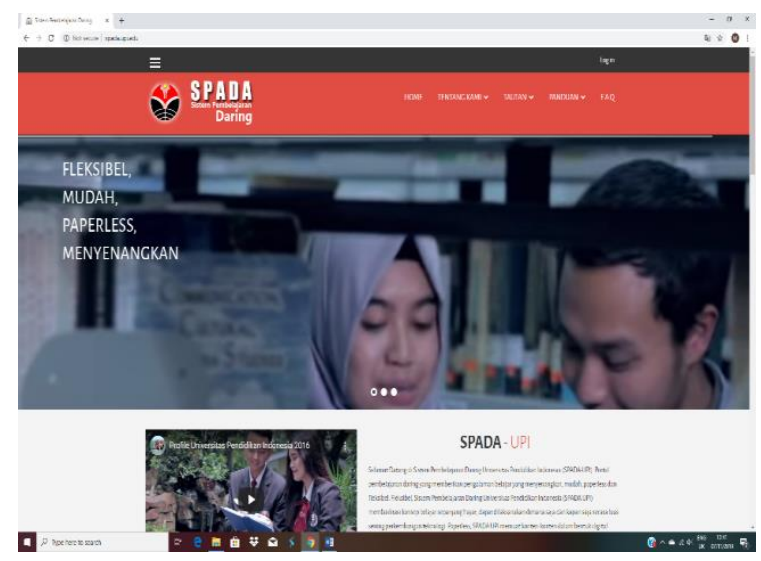

Figure 4 Online lesson SPADA Page at Universitas Pendidikan Indonesia Source http://spada.upi.edu/ 
The development of online-based social studies lesson plan steps require the following principles; (1) looking at the background of the individual abilities of each student, (2) students are participating actively, (3) lesson activities centered on students, (4) the development of lesson activities to improve students' understanding and creativity using digital technology, (5) the follow-up after lesson activities, (6) the integration and relevance of basic competence to achieve lesson objectives, (7) accommodating thematic lesson with the integration of subjects, learning aspects and cultural diversity, (8) learning communication to convey information, and most importantly (9) Application of information and communication technology in an integrated, systematic and effective manner in accordance with the situation and conditions.

Specifically, for the type of evaluation used can be in the form of tests and non-tests, including by utilizing the web or digital-based test application as in Figure 5

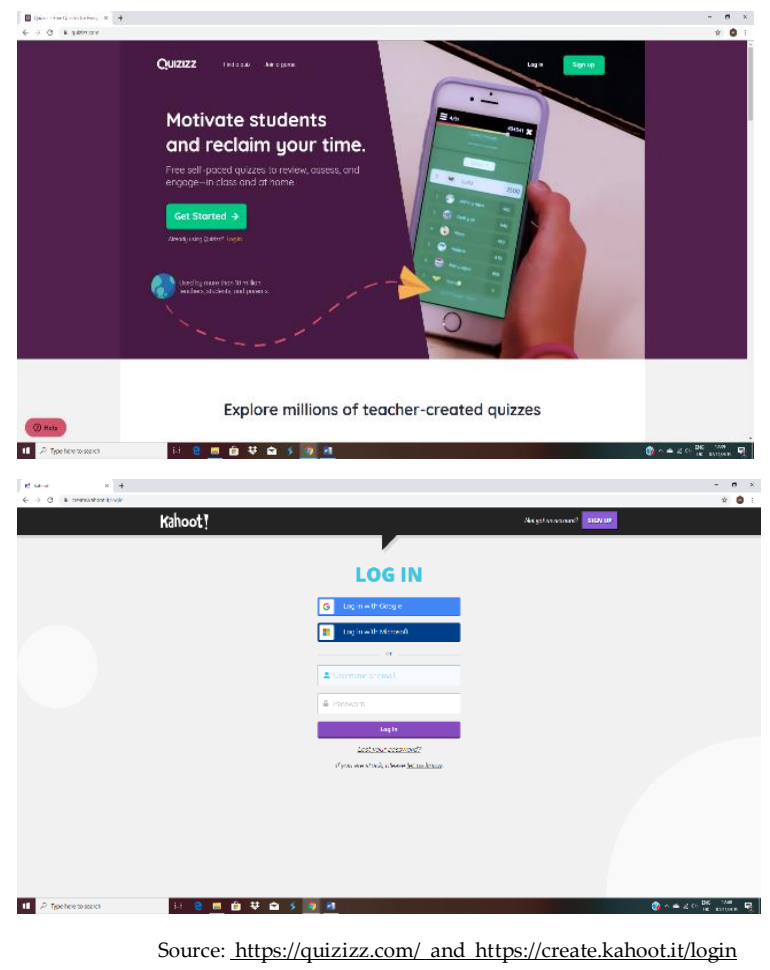

Figure 5 Quizizz and Kahoot Web Pages
The two websites above are only web samples that can be used by teachers in developing tests in evaluating lessons in the classroom. There are still many websites and digital applications that can be used, including Edmodo, Edubox, Quizstar, Thatquiz, Quizzegg, and others. The existence of these websites and applications can make it easier for teachers to develop digitalbased tests, of course, in addition to the test content contained in online lesson websites owned by schools. Digital-based tests can make it easier for teachers to package engaging, useful, and efficient lesson evaluations. Teachers can carry out the test at the same time while simultaneously obtaining students' final scores directly, even for a large number of test participants. Besides, other benefits can overcome the limitations of space, time, and energy, enable students to learn independently, triggers students' learning enthusiasm, and designing attractive test designs.

Overall, online-based social studies lesson plans can provide benefits including the following; (a) motivate students to keep up their enthusiasm for learning according to the demands of the times, (b) attract students' interest and attention to technological advances in the field of lesson, (c) provide opportunity for students to explore situations when experiencing problems in the social environment due to the impact of technological developments in the era of the industrial revolution 4.0, (d) develop student independence, (e) train students to play an active role in real life, (f) equip participants students' knowledge, attitudes, and skills relevant to the needs of the industrial revolution era 4.0.

This online-based social studies lesson plan is one form of innovation in lesson activities aimed at enabling teachers to adjust learning activities following the times. In this digital era, teachers need to be creative with the online-based lesson. Although what has been described by this research is not significant online, at least it is one of the alternative innovations in developing lesson plans that needed in the current lesson system. As a reminder, researchers still 
emphasize that online lesson is only as an additional because educating is the formation of characters that obtained through face-to-face activities in class.

\section{CONCLUSIONS}

It concluded that online-based social studies lesson plans could be implemented in social studies lessons in the classroom as one of the innovations to meet the challenges of developing lesson systems in the digital era of the industrial revolution 4.0. Teachers can make full use of digital devices in full online or half online by providing the required proportions between faceto-face and online-based lessons. This study plan can occur with the support of schools, digital technology devices, the ability of teachers to operate digital devices, and the needs of students. The ability and willingness of teachers, students, schools, parents, and the community are the primary keys to the success of the online-based lesson system.

\section{ACKNOWLEDGMENTS}

We want to express special gratitude to all Social Science Education Study Program of Social Science Education Faculty of Universitas Pendidikan Indonesia stakeholders who facilitated the process of research and writing this article. Then we want to thank students of the Social Sciences Education Study Program who contracted Curriculum Study and Study Plan for their cooperation.

\section{REFERENCES}

[1] Pustekkom. (2019). Survey Pemanfaatan ICT dalam Pembelajaran. Jakarta: Pustekkom.

[2] Nesari, A.J., Heidari, M. (2014). The Important Role of Lesson Plan on Educational Achievement of Iranian EFL Teachers' Attitudes. International Journal of Foreign Language Teaching \& Research, 3(5).

[3] Sesiorina, S. (2014). The Analysis of Teachers' Lesson Plan In Implementing Theme-Based Instruction For Teaching
English To Young Learners. Journal of English and Education.Vol.2(1), p. 84-95.

[4] Milkova, S. (2018). Strategies for Effective Lesson Planning. United States: Michigan University.

[5] Kibret, T.G. (2016). Lesson Planning and Students' Performance Feedback Data Use. Dissertation. Published bySubmitted to Faculty of Psychology in Fulfillment of theRequirements for the Degree ofDoctor of Philosophy. University of KoblenzLandau, Campus Landau.

[6] Nesusin, N. et al. (2014). Development of Lesson Plans By The Lesson Study Approach for The $6^{\text {th }}$ Grade Students In Social Study Subject Based on Open Approach Innovation.Procedia - Social and Behavioral Sciences. Elsevier.ltd. p. 1411 1415. Available online at www.sciencedirect.com.

[7] Hady, W.R.A., Abdulsafi, A.S.T. (2018). How Can I Prepare an Ideal Lesson-Plan?. International Journal of English and Education, 7(4), pp. 2278-4012.

[8] Cicek, V., Tok, H. (2015). Effective Use of Lesson Plans to Enhance Education in the U.S. and Turkish Kindergarten through $12^{\text {th }}$ Grade Public School System: A Comparative Study. International Journal of Teaching and Education,. II(2), pp. 2336-2022.

[9] Brandstrom, C. (2011). Using the Internet in Education - Strengths andWeaknesses: A Qualitative Study of Teachers' Opinions on the Use of the Internet in Planningand Instruction. Thesis. Published by Akademin for Utbilding Och Ekonomi Jerman.

[10] Kanellopoulou, M., Darra, M. (2018). The Planning of Teaching in the Context of Lesson Study: ResearchFindings. International Education Studies, 11(2), pp. 1913-9039.Educational Prossess Standard

[11] Saad, A., Chung, W.H., Dawson, C. (2010). The Development Of Lesson Planning System Based On Case Based Reasoning (CBR) Concept: The Methodology. United Kingdom: 
Proceeding on IADIS International Conferences Informatics.

[12] Kubilinskien, S., Dagien, E.V. (2010). Technology-Based Lesson Plans: Preparationand Description. Informatics in Education. Vol. 9, No. 2, pp. 217-228. Reublik of Indisia. Law No. 22 Year 2016 on

[13] Venkataraman, A. et al. (2017). CollectiveTeach: Crowdsourcing Lesson Plans. Conference 2017, Washington, DC, USA.

[14] Griffin, P., McGaw, B., \& Care, E. (Eds).
(2012). Assesment and teaching of 21st skills. New York : Springer Publishing Company. 